\title{
Beleza roubada: \\ gênero, estética e corporalidade no teatro brasileiro*
}

\author{
Heloisa Pontes ${ }^{* *}$
}

\section{Resumo}

A partir de uma pesquisa mais ampla sobre as inflexões de gênero no campo intelectual e no teatro brasileiro, entre 1940 e 1968, o artigo discute as relações entre estética e gênero e suas implicações nas carreiras das atrizes Cacilda Becker, Maria Della Costa, Tônia Carrero e Cleyde Yáconis. Segundo testemunho dos que a viram representar, Cacilda não foi prejudicada por seus atributos físicos menos favoráveis. A hipótese é de que isso se deve às artimanhas das convenções teatrais, que permitem burlar constrangimentos físicos, sociais e de gênero. Fartamente presente na mídia para retratar, realçar ou diminuir as mulheres sob seu foco, a beleza raramente aparece como dimensão relevante na análise das trajetórias femininas. Daí o interesse em discutir essa questão através de sua refração no processo de construção social das carreiras artísticas.

Palavras-chave: Gênero, Corporalidade e Estética, Atrizes, Teatro Brasileiro, Prostituição e Representação.

\footnotetext{
* Recebido para publicação em setembro de 2009, aceito em novembro de 2009. O artigo beneficiou-se da leitura atenta de minha orientanda, Graziele Andreazza Rossetto, a quem agradeço pelas sugestões e pelo entusiasmo com que vem pesquisando as inter-relações entre a antropologia e a história social do teatro brasileiro, assim como das discussões travadas no âmbito do Projeto Temático Fapesp, "Gênero, corporalidade", coordenado por Mariza Corrêa.

** Professora do Departamento de Antropologia da Unicamp e pesquisadora do Pagu.helopontes@uol.com.br
} 
Stolen Beauty:

Gender, Aesthetics and Embodiment in Brazilian Drama

\begin{abstract}
Drawing from a broader research on gender inflections in the Brazilian intellectual field and in Brazilian drama, between 1940 and 1968, the article discusses the relations between aesthetics and gender, and their implications on the careers of actresses Cacilda Becker, Maria Della Costa, Tônia Carrero and Cleyde Yáconis. According to testimony of those who saw her perform on stage, Cacilda was never hampered by her less favorable physical attributes. The hypothesis is that this is due to the cunning tricks of the conventions of dramatic arts that allow the dodging of social, gender and physical constraints. Widely evoked by the media to portrait, underline or diminish women under its focus, beauty rarely features as a relevant dimension in the analysis of female trajectories. Hence the interest in discussing the subject through its refraction on the process of social construction of artistic careers.
\end{abstract}

Key Words: Gender, Embodiment and Aesthetics, Actresses, Brazilian Drama, Prostitution and Representation. 
Apoiada em uma pesquisa mais ampla sobre as inflexões de gênero no campo intelectual e no teatro brasileiros, entre os anos de 1940 e 1968 (Pontes, 2008), este artigo pretende discutir as relações entre beleza, estética e gênero e suas implicações nas carreiras de algumas mulheres que fizeram nome como atrizes (Cacilda Becker, Maria Della Costa, Tônia Carrero e Cleyde Yáconis). Se no caso das pintoras modernistas, a beleza contribuiu para o sucesso e segurança de Tarsila do Amaral, sua ausência, mostrou Gilda de Mello e Souza, enfronhou Anita Malfatti na problemática expressionista, como eco da "vida que não a fez bonita". Já a atriz Cacilda Becker, segundo testemunho eloqüente dos que a viram representar, não foi prejudicada por seus atributos físicos menos favoráveis. A hipótese é de que isso se deve, antes de tudo, às artimanhas das convenções teatrais, que, potencializadas por uma atriz da estatura de Cacilda, permitem driblar constrangimentos de ordem variada - físicos, sociais e de gênero. Fosse outra a sua profissão, esses atributos teriam sido, se não fatais, ao menos restritivos à ascensão na carreira. Fartamente presente na mídia para retratar, realçar ou diminuir as mulheres sob seu foco, sobretudo em se tratando de modelos, atrizes ou "políticas", a beleza (sujeita, é bom frisar, à relatividade dos padrões culturais e estéticos) raramente aparece como dimensão relevante nas análises de trajetórias femininas feitas por historiadores e cientistas sociais. A não ser como referência ocasional, ligeiramente envergonhada, posto que "menor" diante de coisas "maiores". O contrário, portanto, do que ocorre nas conversas rotineiras de fãs, admiradores ou detratores dessas carreiras.

Saber se os trajes do dia-a-dia de atrizes renomadas ou de algumas primeiras-damas com projeção internacional - Michele Obama, Carla Bruni e a lendária Eva Perón, por exemplo - são tão "expressivos" quanto seus vestidos-de-noite, parece ser uma

1 Citação de Gilda de Mello e Souza retirada do artigo de Nelson Aguilar, "A orientadora" (Miceli e Mattos, 2007:196). 
questão apropriada apenas para colunistas sociais e seus leitores segmentados por classe, gênero e raça, nas diversas revistas que inundam as bancas de jornal. ${ }^{2}$ Mas não para analistas com preocupações mais "sérias". "Fúteis" e "mundanos", esses assuntos sequer chegam a ser considerados objetos dignos de atenção, principalmente se revestidos por uma característica tão volátil quanto a beleza e o "bom gosto". Por isso, poucos são os cientistas sociais que deslindaram a refração desses atributos na construção das carreiras femininas. Os escritores, ao contrário, ligados às dimensões significativas do detalhe, são peritos em esmiuçar o impacto da beleza, das vestimentas e dos juízos estéticos, sancionados socialmente, nas vidas de suas personagens.

Notável nesse sentido é o ensaio "Beleza", de Beatriz Sarlo (2003). Nele, a ensaísta descortina a trajetória acidentada de Eva Perón à luz da importância crescente que seu corpo, seu estilo e suas roupas adquiriram no regime peronista. Atriz mediana de novelas transmitidas pelo rádio (a mídia mais popular d0 período), destituída dos atributos físicos necessários para se ombrear às estrelas da época, Eva Duarte, após o casamento com Perón, tornou-se uma figura central na história política argentina. Atenta a registros inesperados e pouco usuais nas análises disponíveis sobre o peronismo e, em especial, sobre a atuação de Eva como primeira dama, Beatriz Sarlo faz um brilhante escrutínio de sua morfologia corporal, de seus vestidos, penteados, adereços, jóias e poses.

Para entender como Eva Perón construiu um estilo que se converteu em beleza na cena política, Sarlo lança mão da comparação, pois a beleza, relativa à historicidade dos padrões culturais e estéticos, só pode ser apreendida analiticamente em termos de um sistema de relações. No tempo em que se chamava Eva Duarte e estava ligada ao rádio, ela não se destacava em 2 Para uma análise abrangente da lógica que preside a organização desse ramo
da indústria cultural, ver Mira (2001). 
relação aos tipos de beleza reconhecidos no universo da indústria cultural: as ingênuas (com seus sorrisos angelicais, boca e narizes pequenos, graciosas e encantadoras), as atrizes fortes (bocas grandes, carnudas, mulheres com história, interessantes, fortemente sensuais), as notoriamente belas (as atrizes fortes dez anos antes de sê-lo) (Id.ib.:52-53). Eva Duarte não se enquadrava em nenhuma dessas categorias. Sua diferença, segundo Sarlo,

era uma série de qualidades ausentes (nem grandes olhos, nem sorriso segundo a norma, nem corpo excepcional, nem bom gosto, nem poses que denotem bons modos, nem inocência, nem ingenuidade, nem sequer a impressão de ser muito jovem, ainda que fosse de fato). O que Eva não tinha [na época em que tentou a carreira de atriz] era precisamente o que moda exigia como signo da beleza (Id.ib.:56, grifos da autora).

Em 1946, Evita Duarte se converteu na primeira dama Eva Duarte Perón. A partir desse momento, seu rosto, suas roupas, suas poses e seu corpo seriam comparados não apenas aos das atrizes, mas também aos das mulheres da elite. É nesse contexto $e$ no cenário do peronismo que ela e seus atributos físicos, pouco destacados até então, se tornam excepcionais. Nas palavras de Sarlo,

excepcionalidade de primeiro grau" decorrente do traslado para o campo político de "habilidades e destrezas que no campo artístico haviam sido insuficientes, mas que no campo político mostraram seu valor (Id.ib.:70).

Unhas vermelhas, cabelos cada vez mais louros, modelados por um coque que acentuava o formato do crânio $e$ a pele translúcida, vestidos exuberantes para a noite, o traje sério de trabalho do dia-a-dia, tais são as insígnias que paramentam o corpo da primeira dama, que já havia sido treinada como atriz a 
trajar roupas distintas do uso comum. ${ }^{3}$ O que fora uma desvantagem quando Eva almejava uma carreira no rádio e não se destacava pela beleza, tornou-se uma qualidade excepcional e fez dela uma mulher quase atemporal. Misto de duas figuras antológicas do cinema: "uma do passado, Garbo, e outra do futuro, Audrey Hepburn", Eva, em virtude de seu corpo cada vez mais delgado e sem curvas acentuadas, parecia "estar além e acima da moda" (Sarlo, 2003:83). Dessa visada em caleidoscópio da imagem corporal de Eva e da centralidade que sua visualidade passou a ter no dispositivo de propaganda política do regime peronista, resulta uma análise arrojada sobre a importância do corpo real como forma visível do corpo político. ${ }^{4}$

$* * * *$

O ensaio de Beatriz Sarlo, ao descortinar a importância da equação "estética, gênero e corporalidade" para uma apreensão renovada da política, faz ecoar uma observação certeira de Braudel (2007:177):

a história é uma centena de correlações ao mesmo tempo, das quais, na melhor das hipóteses, só percebemos algumas. Portanto, não expliquemos rápido em demasia $e$ a partir de esquemas simples demais.

3 Tendo exercitado seu corpo com roupas mais pesadas que as habituais, Eva sabia portar com desenvoltura os seus grandes trajes de noite, desenhados de início pelo estilista escolhido por Perón: Paco Jaumandreu (que fez carreira como figurinista de cinema e teatro). Responsável pela criação do traje que a singularizou na cena política: um tailler "príncipe de Gales", Jaumandreu se encarregou durante três anos da criação de suas roupas, até que elas passaram a chegar diretamente de Paris, enviadas pela casa Dior.

4 A análise de Sarlo sobre o corpo de Eva Perón se inscreve na linha simbólica descortinada por Kantorowicz em seu estudo sobre o corpo do rei: natural $e$ político. Apoiada na noção a um só tempo filosófica, religiosa e política do corpo duplo do rei, a monarquia assegura sua continuidade no corpo político. Imperecível, ele não está sujeito às contingências que afetam o corpo natural $e$ material do rei (Cf. Kantorowicz, 1998). 
Inspirada pelo vigor da análise de Sarlo e pela ponderação de Braudel, vou examinar a incidência dessa equação no campo do teatro brasileiro, em três registros distintos e interligados: 1) a partir de uma breve comparação entre as atrizes de cinema e de teatro, com o propósito de chamar atenção para a especificidade da prática teatral. 2) a partir da presença da beleza ou de sua ausência no reconhecimento artístico das atrizes Cacilda Becker (1921-1969), Maria Della Costa (1926) e Tônia Carrero (1922). 3) a partir da interpretação que Tônia Carrero e Cleyde Yáconis (1923) deram a duas das mais marcantes personagens da dramaturgia brasileira: as prostitutas Geni e Neusa Suely - criadas por Nelson Rodrigues e Plínio Marcos, respectivamente - com o objetivo de não restringir as relações entre estética e gênero ao plano mais visivel da beleza corporal.

1.

Para os aficionados pelas artes da representação, Greta Garbo e Sarah Bernhardt são nomes obrigatórios. A primeira pelo "glamour" que infundiu à "sétima arte". A segunda pelo que fez nos palcos e fora deles. Divas cuja notoriedade é inseparável dos meios com que se expressaram e das personagens que interpretaram. A primeira ganhou fama no cinema, enquanto a segunda fez nome no teatro. Disso decorrem implicações intrigantes, como a diferença entre as personagens teatrais $e$ cinematográficas.

Greta Garbo marcou o imaginário de milhares de fãs em virtude de sua "inacessibilidade" quase mítica. Ao contrário dos grandes atores e atrizes de teatro, que dão o melhor de si quando interpretam personagens marcantes da dramaturgia ocidental, Greta Garbo, apesar de ter "emprestado" seu corpo para inúmeras personagens femininas, interpretou antes de tudo a si mesma, ou melhor, à "persona" que se construiu em torno dela. Por isso, o que persiste de Garbo não é propriamente a atriz, "mas essa personagem de ficção cujas raízes sociológicas são muito 
mais poderosas do que a pura emanação dramática" - segundo o crítico e estudioso de cinema, Paulo Emílio Salles Gomes. ${ }^{5}$

A menção a Greta Garbo visa realçar uma das mais notáveis diferenças entre o cinema e o teatro quando o assunto é a personagem interpretada. Se em ambos as personagens são encarnadas na pessoa e no corpo dos intérpretes, ocorre que no cinema "os mais típicos atores e atrizes são sempre sensivelmente iguais a si mesmos", pois "em última análise simbolizam $e$ exprimem um sentimento coletivo" (Id.ib.). Além disso, os filmes podem ser revistos, assegurando, assim, uma espécie de imortalidade aos intérpretes. No teatro, ao contrário, atores $e$ atrizes estão sujeitos aos "infortúnios" da temporalidade. "Quando um ator pára o ato teatral, nada fica, a não ser a memória de quem o viu" ${ }^{6}$, segundo palavras daquela que é considerada a maior atriz viva do teatro brasileiro, Fernanda Montenegro.

Apesar de retratados na pintura e de receberem um registro visual preciso a partir da invenção da fotografia, isso não minimiza as injunções da fugacidade a que os atores $e$ as atrizes de teatro estão sujeitos por praticarem uma arte que deixa poucas provas materiais de sua existência. Enquanto o texto encenado pode ser consultado séculos depois da primeira montagem, o espetáculo só sobrevive no testemunho dos que estiveram presentes, nos programas impressos, nas críticas publicadas. Mesmo quando filmado integralmente, ele torna-se outra coisa. ${ }^{7}$ Parte importante

5 Cf. Paulo Emílio Salles Gomes, "A personagem cinematográfica" (Candido, Roselfeld, Almeida Prado e Salles Gomes, 1992:114).

6 Cf. "Aula inaugural" (Montenegro, 1998:13).

7 O registro naturalista que permeia a câmara cinematográfica é também o da fotografia. Mas esta, apesar de ser uma imagem congelada, mostra-se mais aparelhada para captar a "deformação" produzida pelas convenções teatrais tais como os gestos largos e exagerados, a maquiagem carregada, a fisionomia intensa dos atores e das atrizes - tão distinta das imagens afeitas ao "natural" criadas pela televisão e pelo cinema. Diferenças à parte, é preciso não perder de vista que tanto o teatro filmado como as fotografias do espetáculo ou os retratos pintados de atrizes e atores não escapam às questões analíticas e metodológicas postas pelos historiadores da arte quando se defrontam com o problema das 
do "mistério", do "encanto" e da "magia", para usar uma terminologia nativa do teatro, se perde ao ser reproduzida em filme, pois este não é capaz de transmitir aquilo que acontece ao vivo e que depende essencialmente da capacidade de interpretação dos atores e de sua captação pelo público.

Um ótimo exemplo nesse sentido encontra-se na avaliação que o diretor belga radicado no Brasil, Maurice Vaneau, fez sobre o impacto e a força expressiva de uma das mais emblemáticas atrizes do teatro brasileiro, Cacilda Becker (1921-1969). Comparando-a com as grandes atrizes do mundo, Vaneau enfatiza:

(...) que ela tinha um talento de dimensão extraordinária. Quando estava no palco, ocupava-o por inteiro, projetando para toda a platéia (não somente para as duas primeiras fileiras) todos os sentimentos que precisariam ser traduzidos a partir da personagem que estava representando (...). Cacilda tinha esse fluído imenso, emanando ondas, circulando ondas do palco para a platéia, da platéia para o palco e vice-versa, num sistema que é básico para o teatro, porque esse fluído é capaz de tocar o intelecto, o coração, o estômago, os nervos, as artérias e o sangue do espectador. Transitando por personagens muito distintas, Cacilda elevou sua competência como atriz à altura máxima. Eis aî a grande diferença entre a atriz de cinema e a de teatro, pois enquanto a primeira, quando "grande", tende a ser sempre igual a si mesma, no teatro a notoriedade advém da capacidade de encarnar as mais diversas personagens. ${ }^{8}$

mediações necessárias para "ler" um documento visual. Ver a esse respeito, Baxandall (2006). Sobre a análise dos retratos de atores e atrizes, ver Aliverti (1998).

8 Entrevista concedida em 1981 por Maurice Vaneau, reproduzida em Fernandes e Vargas (1995:150-151). 
2.

Se todos que trabalharam com Cacilda Becker ou escreveram sobre ela são unânimes no reconhecimento de sua capacidade extraordinária como atriz, também o são na indicação de alguns de seus atributos físicos menos bem "resolvidos": a voz de curta extensão e de timbre ligeiramente martelado, a estranha maneira que ela tinha de acentuar a última sílaba de cada palavra $e$, principalmente, a magreza extremada para os padrões da época. Tais atributos, porém, nem de longe comprometeram a carreira da atriz. Quando da sua morte prematura e chocante, ocorrida em 1969, como conseqüência de um aneurisma cerebral que a fulminou, aos 48 anos, praticamente no palco - de onde foi retirada às pressas no intervalo de Esperando Godot, ainda vestida com seus trajes de clown - Cacilda era uma atriz consagrada e uma das expressões maiores do teatro brasileiro.

Fosse outra a época, e a sua magreza - que tanto chamou a atenção em virtude dos padrões de beleza vigentes (seu peso raramente atingia 47 quilos) e do fato de que ela parecia literalmente se consumir fisicamente no palco - seria vista com menos reserva nos anos de 1940 e 1950, e com mais adesão, a partir dos anos 60. Comentando as razões que fizeram com que não fosse considerada uma atriz apropriada para o cinema e, em especial, os motivos da fraca repercussão de A luz dos meus olhos, filme que fizera em 1947, Cacilda pondera:

Eu era muito mocinha, tinha um tipo que não era agradável ou não cabia dentro do conceito de beleza da época; era muito magra, magrinha mesma, muito Audrey Hepburn... E fui considerada, na época, pessoa não feita para o cinema, isto é, antifotogênica, de ossos expostos etc. Muitos anos depois, vendo o filme, vi o quanto o conceito de beleza mudara. E eu era aproveitável e poderia ter continuado (no cinema). Não continuei... ${ }^{9}$

9 Trechos do depoimento de Cacilda reproduzido em Prado (2002:226). 
Emitida nos anos de 1960, essa avaliação de Cacilda seria assinada em baixo por Giovani Martucelli, seu cabeleireiro, amigo e um dos admiradores mais entusiastas da imagem corporal da atriz. Impressionado com a sua elegância - nessa época, Cacilda vestia-se na Casa Vogue (a mais sofisticada casa de moda de São Paulo, espécie de Daslu dos anos 60), prestigiava estilistas brasileiros, como Denner, Clodovil e Hugo Castelana, adorava Dior e Chanel - Martucelli ressalta que "ela tinha um corpo espetacular, era magra, tudo nela vestia bem". ${ }^{10}$

Vinte anos antes e a impressão causada por Cacilda fora completamente distinta. À magreza extremada para os padrões de beleza dos anos de 1940, associava-se a ausência de desenvoltura da atriz nos trejeitos e códigos de sociabilidade da vida mundana. Nem propriamente bonita, nem elegante naquele período, Cacilda chamou a atenção de Alfredo Mesquita - crítico, diretor amador e um dos mais empenhados protagonistas do movimento de renovação do teatro brasileiro - pela ausência quase absoluta desses atributos. Tendo visto Cacilda representar pela primeira vez em 1941, na peça Coração, encenada pela Companhia de Raul Roulien, Alfredo Mesquita relembra a imagem confrangida da atriz iniciante na recepção que o pintor Di Cavalcanti e sua mulher, Noêmia, ofereceram ao elenco da Companhia. Nas palavras de Alfredo Mesquita (1995:82-83):

Com a brilhante chegada dos atores e várias rodadas de whisky, a reunião animou-se, subiu de tom. Num canto, só, encolhidinha, um copo de Coca-Cola a tremelicar-lhe nas mãos trêmulas, os olhões arregalados, visivelmente assustada, lá estava a artistazinha que há pouco, no palco, chamara-me a atenção ("pela maneira simples e justa com que representava") (...) Cumprimentei-a pela interpretação daquela noite, tentei puxar prosa, animá-la. Em vão. Forçava um sorriso, que não vinha. Apenas a boca repuxava-se num quase esgar, enquanto os olhos fixavam-

${ }^{10}$ Trechos do depoimento de Martucelli reproduzido em Prado (2002:488). 
me apavorados. Para não prolongar o martírio, achei melhor abandonar a "missão". Foi o que fiz sem lhe ter ouvido a voz, uma palavra sequer.

O depoimento de Alfredo Mesquita é notável pelo que diz abertamente e pelo que sugere nas entrelinhas. Como membro da poderosa família Mesquita, dona de O Estado de S. Paulo, Alfredo fora socializado no universo da elite paulista e tinha de sobra o que se pode chamar de "savoir faire" ou, para usar uma terminologia sociológica, o seu "habitus" internalizado sob a forma de disposições corporais e esquemas de avaliação $e$ percepção. Assim, quando de seu primeiro encontro com Cacilda, de quem se tornaria amigo e admirador, ele "pinçou", sem meias palavras e com aquela condescendência própria dos muito seguros socialmente, as "fragilidades" iniciais de Cacilda, antes dela se celebrizar como a "primeira atriz" do Teatro Brasileiro de Comédia (TBC), nos anos de 1950, e virar a "mulher elegante" da década de 1960. Quais sejam: a falta de "beleza" e de "traquejo" social. Cada uma, em separado, talvez não chamasse tanto a atenção de Alfredo. Pois se atrizes como Laura Suarez (uma das vedetes da época) e Bibi Ferreira podiam transitar com facilidade do português para o francês e deste para o inglês, o mesmo não se pode dizer da maioria das atrizes profissionais da época, que, diferentemente dos amadores, vinham de famílias humildes ou de classe média baixa, muitas delas ligadas ao teatro de revista ou mambembe, com precária formação escolar. Mas se a origem era "baixa", as "maiores" podiam compensar essa "falta" com algum trunfo físico particular, como a beleza no caso de Tônia Carrero e Maria Della Costa.

Não sendo bonita como Maria Della Costa - com seus olhos azuis, nariz afilado, abundantes cabelos louros, alta e elegante, espécie de Catherine Deneuve local - Cacilda partilhava com ela uma origem social das mais humildes. Se a inserção na vida profissional do teatro permitiu-lhe uma profusão de conquistas importantes, nem por isso apagou as marcas doídas da pobreza $e$ 
o sentimento de humilhação que experimentara na infância e na adolescência. $\mathrm{O}$ acesso a círculos de sociabilidade impensáveis para alguém de sua origem social, propiciado pela bem-sucedida carreira no teatro, a aquisição de uma série de bens materiais e simbólicos, entre eles, o "nome próprio", a vivência de relações amorosas marcantes (com Tito Fleury, seu primeiro marido e, por um tempo, ator profissional; com o diretor italiano Adolfo Celi; e, por fim, com o ator e diretor Walmor Chagas, com quem fundaria a própria companhia, o Teatro Cacilda Becker, ao sair do TBC, em 1957) e, sobretudo, a chancela da maior atriz do período foram essenciais para o equacionamento da imagem pública e da auto-imagem da atriz. Mas não para o esfacelamento dos sentimentos mais sofridos e tumultuados advindos da vivência funda da pobreza, os quais se entranhavam nela sob uma forma distinta da héxis corporal exibida pelos socialmente excluídos. No caso de Cacilda, com a soberania e desenvoltura próprias das grandes atrizes que, sujeitando os corpos ao trabalho de suporte de experiências alheias, por vezes bastante longínquas de suas vivências pessoais e familiares, dominam as convenções teatrais a ponto de infundir aos sentimentos uma pletora de significados novos e inesperados. Não só por um ato de vontade intelectual, mas, principalmente, pelo que conseguem fazer corporalmente com eles. Nessa "incorporação" da experiência alheia, burlam convenções sociais de classe, de gênero e de idade, imprimindo às personagens que representam verossimilhança $e$ verdade renovadas com aquela voltagem eletrizante, os tais "feixes de nervos", que o público sabe reconhecer quando é fisgado pelo desempenho delas no palco, embora só alguns, como Décio de Almeida Prado, tenham sido capazes de traduzir com tanta precisão em palavras.

Nem bonita nem bem formada, em razão da origem social e da precária escolarização, "marcada" para sempre, em suas palavras, "pela pobreza", Cacilda triunfou porque elevou à máxima altura a sua competência como atriz, em um contexto muito particular de renovação do teatro brasileiro. Contando com 
a experiência acumulada dos diretores estrangeiros - que para cá vieram em decorrência de perseguições étnicas acentuadas durante a Segunda Guerra Mundial, como Ziembienski, ou de condições pouco animadoras de trabalho no pós-guerra, caso dos italianos que passaram pelo TBC, Adolfo Celi, Ruggero Jacobbi $e$ Gianni Ratto ${ }^{11}$ - Cacilda pôde suprir as deficiências de sua formação, driblar seus atributos físicos menos favoráveis, familiarizar-se e dominar as técnicas e as convenções teatrais que fizeram do TBC o modelo por excelência do teatro brasileiro até meados dos anos de 1950. Acreditando totalmente no trabalho de direção, ela aprendeu com os diretores estrangeiros uma maneira nova de representar, distinta daquela que, segundo Adolfo Celi, advinha de "uma descendência portuguesa do velho teatro, que correspondia a uma velha maneira de representar na Itália". ${ }^{12}$ Disposto "a acabar" com essa tradição, Celi, ao ser contratado para o TBC em 1949, encontrou em Cacilda a atriz ideal para levar adiante o seu projeto de renovação teatral. Profissional impecável, pontual, disciplinada, ela era a primeira a chegar e a última a sair do teatro. Entregava-se "totalmente ao papel" que estava fazendo e "amava repetir" as suas falas até a "exaustão" (Fernandes e Vargas, 1995:121).

Nas palavras de Ziembinski, o diretor com quem mais trabalhou ao longo de sua carreira (ao todo, ele a dirigiu em dez peças, quatro no TBC e seis no TCB), um dos "slogans" de Cacilda, quando lhe propunha um novo espetáculo, era: "Vamos trabalhar! Vamos ter um trabalho infernal!". Para ela, prossegue Ziembinski:

${ }^{11}$ Sobre a atuação desses diretores, consultar Guzik (1998 e 1986), Almeida (1987), Guzik e Pereira (1980), Almeida Prado (1988), Raulino (2002). Ver também os depoimentos de Adolfo Celi, Ruggero Jacobbi e Gianni Ratto em Fernandes e Vargas (1995), bem como o livro de memórias de Gianni Ratto (1996).

${ }^{12}$ Trecho da entrevista que Adolfo Celi concedeu em março de 1981, em Roma, para Júlio Lerner (Fernandes e Vargas, 1995:124). 
Trabalho infernal era fonte de alegria, de necessidade de esforço extremo. No calor do trabalho, da luta para conquistar novos valores, ela se sentia renascer, ao mesmo tempo em que o corpo frágil se transformava em corpo de gigante, um corpo iluminado. ${ }^{13}$

Cacilda Becker

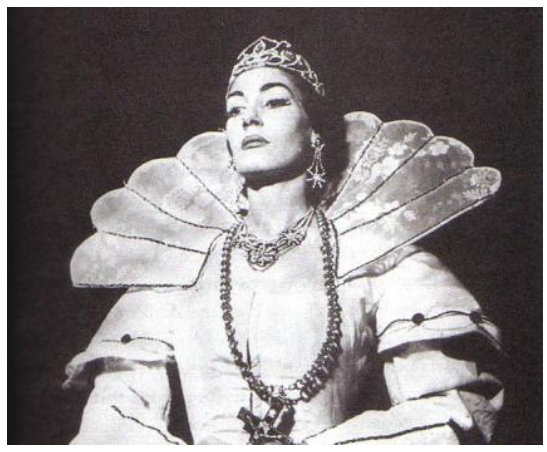

como Mary Stuart, em 1955,

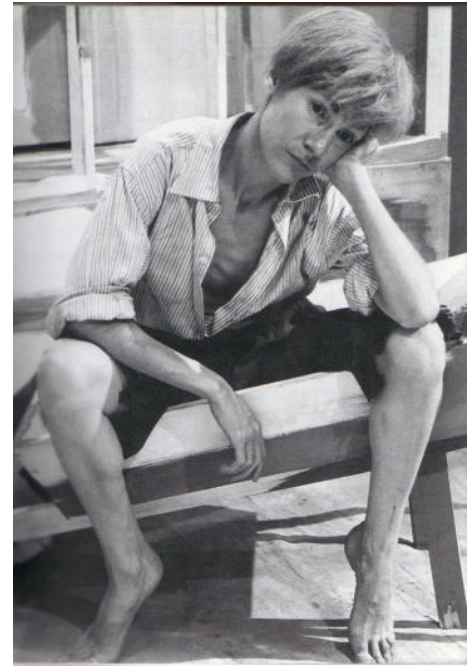

como menino Pega-Fogo

TBC, 1950

${ }^{13}$ Trecho do depoimento de Ziembinski apresentado no programa "Homenagem a Cacilda", Rádio, Televisão e Cultura, Canal 2, em 6 de abril de 1979 (Fernandes e Vargas, 1995:142). 
O qual permitia-lhe transitar por personagens muito distintas, da rainha Mary Stuart ao menino Pega-Fogo. Não só em virtude dos aparatos externos que ela mobilizava para dar verossimilhança às personagens encenadas - o traje majestoso com que se paramentava de rainha ou o esparadrapo com que apertava os seios debaixo da camisa para tornar mais crível a sua representação de menino - mas, sobretudo, pela capacidade de converter a experiência da humilhação e privação vividas na infância $e$ adolescência em uma poderosa chave interpretativa como bem souberam reconhecer as pessoas que lhe eram mais próximas por estarem inteiramente imersas, como ela, no mundo do teatro, na condição de atores, diretores ou críticos. Comentando o desempenho de Cacilda em Pega-Fogo, Adolfo Celi ressalta que:

foi a coisa mais bonita que vi dela. Foi uma coisa extraordinária. (....) Ela conseguiu mostrar toda a sua infância, uma infância que não deve ter sido fácil. Ela conseguiu transmitir toda essa dor, a dor de uma criança que não foi feliz, que nunca foi feliz. ${ }^{14}$

Avaliação corroborada também pelo crítico Sábato Magaldi, que, desconcertado com a constatação de que os dois papéis de sua predileção na carreira da atriz eram masculinos (Pega-Fogo $e$ Estragon, em Esperando Godot), desvela o significado dessa coincidência. A seu ver, ela advinha não do fato de que Cacilda "aparentasse masculinidade em cena". Ao contrário,

Ela era bem feminina, em tantas criações. [Sua fragilidade pessoal, pondera Sábato] é que emprestava a Pega-Fogo e a Estragon, o corte profundamente humano. Desamparo, tristeza, perplexidade diante da vida, sofrimento contido, humilhação - eram a matéria-prima que vinha das raízes da

\footnotetext{
${ }^{14}$ Trecho da entrevista de Adolfo Celi a Júlio Lerner (Fernandes e Vargas, 1995:120).
} 
infância e se colava às personagens, fazendo-as tão autênticas. ${ }^{15}$

Masculinos, esses dois papéis são a expressão contundente do quanto o "nome próprio" se associa, no caso das grandes atrizes - como a italiana Eleonora Duse, a russa Ludmilla Pittöeff, as brasileiras Fernanda Montenegro e Cacilda Becker - à corporificação dos mecanismos de burla produzidos pelas convenções teatrais. Fazendo do corpo o suporte mais importante, o teatro permite às grandes atrizes contornar os imperativos implacáveis da beleza e os constrangimentos impostos pelo envelhecimento. $\mathrm{O}$ que dificilmente ocorre em outros domínios, como o cinema, o balé clássico e a moda, marcados pela centralidade do corpo. Assim, atrizes como Cacilda dão o que pensar sobre o lugar da beleza na atividade artística.

Quem levou mais longe essa reflexão foi Gilda de Mello e Souza em seu último artigo, dedicado àquele que a ensaísta considerava o maior dançarino moderno, Fred Astaire (18991987). A adesão à modernidade de Fred Astaire revelava-se na maneira de cantar, na seleção dos compositores, na escolha dos trajes (a casaca preta, a cartola, a bengala, os sapatos pretos de verniz) e, sobretudo, no modo como usava e ajustava o corpo à indumentária - a leveza desentranhada do figurino de gala. Fred Astaire dançava e saltava "como se não houvesse pernas", por isso o que apreendemos dele "é o arabesco das abas da casaca em pleno vôo, a nitidez gráfica do desenho, o preto no branco". ${ }^{16}$

Reduzindo o corpo "a um suporte do gesto, não simbolizando em nenhum momento a beleza muscular e a plástica corporal, como fazem o balé clássico e Gene Kelly", Fred Astaire liberava e, ao mesmo tempo, encenava a "beleza do gesto - pura, livre, autônoma e descarnada" (Id.ib.:172). E, para isso, contribuiu

${ }^{15}$ Cf. Sábato Magaldi, "À maneira de prefácio e depoimento" (Fernandes e Vargas, 1995:19).

${ }^{16}$ Cf. "Notas sobre Fred Astaire" (Mello e Souza, 2005:176). 
o fato de não ter sido um homem bonito, pois, "sendo como era, manteve-se gesto, gesto puro, graça pura, libertando-se dos cacoetes da mocidade para se tornar na dança um desenhista, um dançarino gráfico, puro arabesco sem cor" (Id.ib.:177). Nessa química paradoxal, em que a beleza projetada pelo artista moderno só se manifesta integralmente quando esbate o suporte corporal, reside a genialidade do dançarino e também das intérpretes de corpo iluminado como Cacilda Becker.

3.

Longe de ser um trunfo, a beleza, na visão de Décio de Almeida Prado - o crítico e historiador maior do teatro brasileiro podia ser um complicador. Tal era, a seu ver, o caso de Maria Della Costa. Nas palavras de Décio:

O obstáculo maior [que ela enfrentou] para chegar aonde chegou [foi] a beleza, que a marcava entre as outras mulheres, abrindo-lhe uma série de carreiras fáceis, capazes de deslumbrar qualquer jovem. Maria Della Costa foi "girl", exibiu-se nos cassinos, passou pelas casas de moda, como "modelo", e de toda essa experiência trouxe o hábito do trabalho, a consciência profissional, a ambição de ser uma grande atriz (...) Sem qualquer cultura literária especial (não houve tempo para isso) preferiu sempre o bom teatro, com essa humildade perante a arte que é a sua melhor qualidade e a mais rara numa mulher bonita. Estudou, submeteu-se, voluntariamente, assim que pôde, à disciplina de um encenador, fazendo questão de criar uma companhia baseada não na exaltação de sua pessoa, mas no valor do conjunto (Almeida Prado, 1988:228, grifos meus).

O comentário de Décio de Almeida Prado é parte de uma crítica maior que ele escreveu em 1955, quando da estréia do Teatro Maria Della Costa, feita com a peça O canto da cotovia, de Jean Anouilh, na direção impecável do cenógrafo e diretor Gianni Ratto. Abordando de passagem a trajetória e a carreira da 
"primeira atriz" da companhia, Décio chama atenção para o lugar paradoxal que a beleza tem no universo do teatro. Espécie de "abre-te Sésamo" em profissões como as de modelo, quase essencial para deslanchar uma carreira no cinema, a beleza, para as atrizes de teatro, pode ser um obstáculo a superar. Marca poderosa, se "colada" demais à figura da atriz, a beleza pode ser um empecilho para que ela leve adiante o trabalho exigido pelas convenções teatrais. Impedindo, assim, que encene corporalmente a plêiade de personagens disponíveis na dramaturgia teatral. Tal foi o caso de Tônia Carrero.

Atriz de feitio realista, talhada como poucas pela beleza $e$ pelo "timing" para a comédia requintada, tão bem captados em suas interpretações no cinema, Tônia Carrero nunca atingiu o grau de "perfeição" propiciado pelos mecanismos de burla teatral. Mas aprimorou-se como atriz entre o início de sua primeira companhia em 1949, e o final da segunda, em 1961 entremeados pela temporada na companhia cinematográfica Vera Cruz e pela rápida e tumultuada passagem pelo TBC em 1954 especialmente quando subiu ao palco em 1967, na pele de Neusa Suely, a prostituta de Navalha na carne. A peça de Plínio Marcos foi um divisor de águas na dramaturgia nacional e na carreira de atriz. Nesse papel, Tônia "despiu-se" da personagem maior que encarnou por tanto tempo: a mulher elegante e sofisticada, "condenada", como atriz, aos infortúnios da "beleza incomum". Despojada e aguerrida, Tônia expôs no palco um lado até então desconhecido da prostituição, numa linguagem nada usual para época, e ganhou o reconhecimento unânime da crítica.

Outra prostituta célebre do teatro moderno brasileiro, Geni, personagem da peça Toda nudez será castigada, de Nelson Rodrigues, foi interpretada por Cleyde Yáconis. A oportunidade para encenar um texto de Nelson Rodrigues veio do convite feito pelo próprio dramaturgo, em 1964. "Desesperado" com a recusa de outras atrizes, entre elas, Fernanda Montenegro e Teresa Raquel, Nelson ligou para Cleyde com o propósito de convencê-la a aceitar o papel de Geni, a protagonista de Toda nudez será 
castigada. Quando soube que Ziembinski seria o diretor e que o elenco seria composto por Luiz Linhares, Nelson Xavier e Elza Gomes, ela aceitou, antes mesmo de ler a peça. ${ }^{17} \mathrm{~A}$ "assinatura" do dramaturgo e a direção daquele que até então melhor entendera a obra de Nelson Rodrigues já lhe pareciam suficientes para atestar a qualidade do texto e para dirimir qualquer dúvida sobre a potencialidade teatral da personagem que viveria no palco: a prostituta obcecada com idéia de que teria um câncer nos seios, para quem, nas palavras de Cleyde, "o sexo era uma coisa que, lavando, não atingia a alma" (Id.ib.:86). No primeiro ato da peça, entre as frases ditas por Geni que causaram indignação em muitos e "frisson" em outros, estavam a de que ficava "toda molhadinha" só de ver Herculano, sempre disposta a fazer com ele "um outro amorzinho bem gostoso", antes de lançar mão da sentença "você só toca em mim casando! Só toca em mim casando". ${ }^{18}$ A tragédia carioca "mais concisa e enxuta" de todas as que foram escritas por Nelson Rodrigues, na avaliação de Ziembinski $^{19}$, foi encenada pela primeira vez $-e$ não aleatoriamente - no Rio de Janeiro, em junho de 1965, numa estréia concorrida, com o "público de pé, estupefato, aplaudindo, gritando". ${ }^{20}$

Era a primeira vez que Cleyde subia ao palco como atriz independente, fora dos quadros de uma companhia fixa, depois do encerramento do TBC no ano anterior. No papel de Geni ela foi aplaudida em cena aberta e ganhou o prêmio mais cobiçado da época: o Molière, o mesmo que Tônia recebeu dois anos depois pela interpretação da prostituta Neusa Suely, de Navalha

\footnotetext{
${ }^{17}$ Informação obtida na entrevista de Cleyde Yáconis para a revista do Sesc, $A$ terceira idade, vol.16, $\mathrm{n}^{\circ}$ 30, fevereiro de 2005.

${ }^{18}$ Cf. "Toda nudez será castigada" (Rodrigues, 2004:130).

${ }^{19} \mathrm{~A}$ avaliação de Ziembinski é parte do texto que ele escreveu com o título "A ciranda do Nelson", para o programa da montagem que estreou em 1965, no Teatro Serrador.

${ }^{20}$ Trecho da entrevista que Cleyde concedeu a Vilmar Ledesma (Ledesma, 2004:155).
} 
na carne. Para fazer Geni e entender um mundo que lhe era totalmente desconhecido, Cleyde foi diversas vezes ao bairro carioca da Lapa, com o intuito de ouvir, observar, apreender a vida das prostitutas baratas, muitas delas meninas, entre os 12 e os 14 anos, expulsas de casa pelos pais, depois de "darem o tal do mau passo". Por isso, segundo a atriz, elas ficavam "mentalmente paradas nessa idade" $e$ isso aparecia em seus quartos nos prostíbulos: "nos babadinhos cor de rosa, na boneca em cima da cama, na leitura delas, Grande Hotel, revista de fotonovelas, folhetim" (Id.ib.:90).

Ao lado dessas imersões no "campo", leituras diversas sobre o assunto. $\mathrm{O}$ resultado, além da empatia e compreensão alargada da vida dessas meninas, apareceu na composição final da personagem, com a ajuda de sua competência como intérprete e da visão certeira de Ziembinski. Rompendo com a convenção da "puta tradicional da saia preta aberta com meia rendada preta $e$ salto alto", o diretor propôs a Cleyde que trajasse a personagem com a mesma roupa que costumava usar durante os ensaios: "um tubinho de algodão vagabundo, listradinho, cor de rosa e branco", que a atriz havia costurado para agüentar o "calorão" do Rio. Vestida assim, calçando chinelo e sem um pingo de maquiagem, Cleyde arrasou no palco, ao mostrar uma prostituta que falava palavrão, mas continuava "intelectualmente aquela menina do Grande Hotel, boneca em cima da cama", para quem bastava, como ela dizia, "lavar a xoxota e pronto" (Id.ib.).

Se no teatro Cleyde Yáconis se destacou em inúmeras interpretações, entre elas, a prostituta Geni, na televisão participou de várias novelas, representando quase sempre o papel de grãfina, capaz de subir num salto alto como poucas, e com uma elegância e desenvoltura que nada lembram ou deixam flagrar a experiência pessoal de privação que sofreu na infância $e$ adolescência. Não só ela como Maria Della Costa, Fernanda Montenegro e, especialmente Tônia Carrero, cujo reconhecimento como atriz veio aos poucos e de forma tortuosa, principalmente da 
parte dos críticos, e só alcançou a unanimidade quando interpretou Neusa Suely.

Não parece aleatório que tanto Cleyde quanto Tônia tenham tido esse enorme reconhecimento justamente no papel de prostitutas, quando o assunto veio à baila nos palcos brasileiros de forma totalmente inovadora na pena irreverente dos dramaturgos Nelson Rodrigues e Plínio Marcos. As peças de ambos continuam vivíssimas, ainda que o impacto causado não se repita mais com a intensidade de antes, menos pela ausência de atrizes capazes, $e$ mais em virtude da banalização que o assunto sofreu em decorrência da liberação dos costumes e da sexualidade. Mas o gosto que as atrizes têm em representar prostitutas permanece. ${ }^{21}$

Esse fascínio, verdadeiro "deslumbramento", nas palavras de Nelson Rodrigues, que a representação da prostituta exerce sobre as atrizes, chamou a atenção do dramaturgo no período em que acompanhou os ensaios de Vestido de noiva (encenada em 1943) e se surpreendeu com a demanda de uma das intérpretes amadoras, de "boa família" que, aos gritos e com "paixão" pedia pelo papel de Madame Clessy. A seu ver, "não há atriz que não queira usar o vestido, os modos, as caras, as inflexões, os risos das 'filhas da desgraça'. Isso aqui, em toda parte e em todos os

${ }^{21} \mathrm{O}$ apelo que essas personagens despertam, proporcional à popularidade que as intérpretes podem conquistar ao fazê-las, acontece tanto no teatro como na televisão. Exemplo recente nesse sentido é o da prostituta Bebel, da novela Paraíso tropical, de Gilberto Braga, exibida pela Globo em 2007. Nesse papel, a atriz Camila Pitanga ganhou o público e se tornou um "must" das passarelas de moda, das revistas de celebridades e das publicações de luxo, como a Vogue, da qual foi capa por duas vezes em 2007 e "recheio" em sofisticadas e estilizadas reportagens fotográficas. Não aleatoriamente também essa mesma revista, em fevereiro de 1968 - meses depois da consagração de Tônia Carrero no papel da prostituta Neusa Suely - estampou a atriz na capa e fez com ela um longo ensaio fotográfico, no qual encarnava a "mulher elegante" e de elite para a qual a publicação se destina. Treze anos mais tarde, em 1981, depois do sucesso como a grã-fina Stela, na novela Água viva, de Gilberto Braga, ela foi assunto novamente da Vogue na reportagem "Tônia Carrero: sparkling". Informações obtidas no dossiê "Tônia Carrero", disponível para consulta no Centro de Documentação e Informação da Funarte, localizado no Rio de Janeiro. 
idiomas" (Rodrigues, 2002:202). Nesse papel - prossegue Nelson as atrizes se transfiguram:

Não há atriz, por mais inepta, mais incompetente ou medíocre, que represente mal a prostituta. Aí está o papel irresistível. A meretriz do teatro é perfeita. Não importa que a intérprete seja uma canastra. De repente, ela se põe a dizer, a inflexionar, a gesticular como uma [Eleonora] Duse (Id.ib.).

O comentário de Nelson Rodrigues pode ser ampliado para a discussão dos mecanismos de burla, propiciados e estimulados pelas convenções teatrais, quando postos a serviço do desvendamento dos constrangimentos sociais que recaiam sobre as mulheres na época e, em especial, sobre as atrizes. Se, no período de implantação e consolidação no país do teatro moderno, as intérpretes haviam conquistado prestígio e status decorrentes da assinatura que produziram na cena teatral, elas ainda podiam sofrer os revezes do rebaixamento social pela associação enviesada da profissão com as artimanhas da dissimulação presentes no universo da prostituição. Meia-verdade e não a verdade inteira, essa explicação precisa ser inscrita num registro mais polêmico e, por isso mesmo, mais incômodo. Para enfrentá-lo, sigo aqui as "proposições elementares" de Annie Mignard. Segundo a autora,

Se a prostituição não pode deixar as mulheres indiferentes, é porque elas sabem que a relação dos homens com a prostituta é a relação deles com as mulheres em geral, ou antes com a imagem que colocam no lugar das várias mulheres do Real. Se as mulheres não raro se sentem fascinadas, ou mesmo tentadas, pela prostituição, é como o caso-limite de uma representação cujo poder e impostura só elas são capazes de conhecer (Mignard, 1976:1540-41). ${ }^{22}$

\footnotetext{
${ }^{22}$ Vale enfatizar que a discussão sobre a prostituição feita nesse segmento visa apenas à apreensão do tema no âmbito das convenções teatrais e suas
} 
Inspirado pelas "considerações elementares" da autora a respeito da prostituição, o historiador da arte T.J. Clarck faz um uso preciso (e certeiro) para desvelar os significados ocultos, apesar de visíveis na tela, que o tema recebeu num dos quadros mais famosos da pintura moderna, Olympia, de Manet. Assim como a dramaturgia francesa do século XIX é repleta de cortesãs e prostitutas, o mesmo se dá na pintura, de maneira mais ou menos dissimulada pelas convenções pictóricas da época. O escândalo produzido pela exibição em 1865 de Olympia deve-se, segundo Clarck, ao fato de que nesse quadro os "significantes do sexo estão ali em profusão, no corpo e nos seus acompanhamentos" (Clarck, 2004:198). Dispostos, no entanto, numa ordem diversa das convenções utilizadas para retratar as prostitutas, as cortesãs $e$ seus corpos, tais signos indicam lugares totalmente distintos dos esperados para as mulheres da mesma extração social da modelo que se deixou retratar por Manet. Por isso, segundo Clarck, a dificuldade maior dos críticos diante da Olympia advinha, paradoxalmente, do fato de que ela não fazia parte do jogo da prostituição tal como retratado na pintura - e, acrescentaria, tal como encenado no palco na época. Não porque ela não fosse pintada como uma prostituta e, sim, por ter sido pintada sem subterfúgios, exibindo em sua nudez o signo indelével de sua classe. Por classe, o historiador da arte, entende:

um nome dado àquele lugar complexo e determinado que nos é designado no corpo social; o nome dado a tudo aquilo que significa que uma certa história que vive em nós, nos confere nossa individualidade. Por nudez quero designar aqueles signos - aquele circuito intermitente $e$

implicações na carreira das intérpretes, deixando de lado a ampla bibliografia que vem sendo produzida sobre o assunto, sobretudo aquela interessada em inscrever a questão a partir da articulação entre gênero e corporalidade. Ver a esse respeito, os trabalhos de Adriana Piscitelli, em especial, "Corporalidades em confronto: gênero e nacionalidade no marco da indústria transnacional do sexo" (2007). 
interminável - segundo os quais não estamos em lugar algum senão num corpo, que somos construídos por ele, pelo modo como ele incorpora os signos de outras pessoas. (...) A nudez consiste em um forte signo de classe, uma instância perigosa dela. E por esse motivo a reação dos críticos em 1865 se torna mais compreensível. Eles ficaram perplexos diante do fato de que a classe de Olympia não estava em lugar algum, a não ser no corpo dela: o gato, a negra, a orquídea, o buquê de flores, os chinelos, os brincos de pérola, o cordão no pescoço, o biombo, o xale - pistas falsas, que nada significavam, ou ao menos nada em particular (Id.ib:208-209).

Guardadas as devidas mediações - de tempo, lugar e gênero de produção, se teatro ou pintura - o impacto produzido pelas interpretações que Cleyde Yáconis e Tônia Carrero deram às prostitutas de Nelson Rodrigues e de Plínio Marcos advém também da verossimilhança que elas estamparam nos corpos de suas personagens, com o auxílio das roupas e insígnias do chamado "submundo". O vestido listradinho, os chinelos $e$ nenhuma maquiagem, no caso da Geni. O palavrão, o jargão "chulo", a economia verbal, no caso de Neusa Suely. Nessa linguagem e nesses trajes residem as marcas de classe dessas prostitutas. Nelas se operam o "desnudamento brutal" - nas palavras de Anatol Rosenfeld -, "sem uma gotinha de dietil, sem disfarces e sem ambigüidade" ${ }^{23}$, desse universo até então ignorado pela dramaturgia brasileira.

Que elas tenham sido interpretadas por duas atrizes tão diferentes - a atriz de repertório, Cleyde Yáconis, e a atriz empresária, Tônia Carrero - no momento de esvaziamento do paradigma teatral em que ambas se formaram e de seu enquadramento institucional sob a égide das companhias com elenco fixo, dá o que pensar em duas direções. De um lado,

${ }^{23}$ Trechos do artigo que Anatol Rosenfeld escreveu em 15/07/1967 para O Estado de S. Paulo, reproduzidos no programa da peça Navalha na carne, 1967. 
aponta para o quadro das condições que viabilizaram a aclimatação do teatro moderno no país, em sua oscilação (e fascínio) pelo repertório "estrangeiro" $e$ as incursões pontuais pela dramaturgia nacional. De outro lado, mostra que o impacto dessa dramaturgia, para além de suas qualidades literárias internas, dependeu da força interpretativa dessas atrizes. E, nesse sentido, não parece aleatório que tenham sido elas, com a colaboração ativa dos diretores, as principais responsáveis na época pela encenação transgressora da "natureza imaginária do gênero". ${ }^{24}$ Isto é, pela desconstrução dos marcos sociais, eróticos e cognitivos que conformavam a representação no palco da prostituição. Nesse entrelaçamento entre dimensões estéticas avessas ou refratárias aos padrões então vigentes de beleza e uma corporalidade plena de agência e, por isso mesmo, apta a inovar as convenções teatrais, reside uma das interpretações possíveis. Para finalizar, relembro a observação de Braudel que serviu, junto com o ensaio de Beatriz Sarlo, de inspiração para este artigo: "a história [assim como a antropologia] é uma centena de correlações ao mesmo tempo, das quais, na melhor das hipóteses, só percebemos algumas" (Braudel, 2007:177).

\section{Referências bibliográficas}

ALIVERTI, Maria Inês. La naissance de l'acteur moderne: l'acteur et son portrait au XVIII siècle. Paris, Gallimard, 1998.

AlmeidA, Maria Inez Barros de. Panorama visto do Rio: Companhia Tonia-Celi-Autran. Rio de Janeiro, Inacen, 1987.

Almeida PRADo, Décio de. O teatro brasileiro moderno. São Paulo, Perspectiva, 1988.

BAXANDAlL, Michael. Padrões de intenção: a explicação histórica dos quadros. São Paulo, Companhia das Letras, 2006.

${ }^{24}$ A expressão é de Mariza Corrêa e serve de título para seu belo artigo, "A natureza imaginária do gênero na história da antropologia" (1995). 
BRAudel, Fernand. O modelo italiano. São Paulo, Companhia das Letras, 2007.

Candido, Antonio; Roselfeld, Anatol; Almeida Prado, Décio de e SAlles Gomes, Paulo Emílio. A personagem de ficção. São Paulo, Perspectiva, 1992.

FERnANDES, Nanci e VARGAS, Maria Tereza. Uma atriz: Cacilda Becker. $2^{a}$. ed. São Paulo, Perspectiva, 1995.

Clarck, T. J. A pintura da vida moderna. Paris na arte de Manet e de seus seguidores. São Paulo, Companhia das Letras, 2004.

CORRÊA, Mariza. A natureza imaginária do gênero na história da antropologia. Cadernos Pagu (5), Núcleo de Estudos de Gênero Pagu/Unicamp, 1995.

GuzIK, Alberto. Paulo Autran: um homem no palco. São Paulo, Boitempo, 1998.

. TBC: crônica de um sonho. São Paulo, Perspectiva, 1986.

e Pereira, Maria Lúcia. (orgs.) Dionysos, $n^{\circ} 25$, Rio de Janeiro, setembro de 1980.

KANTOROWICZ, Ernest. Os dois corpos do rei: um estudo sobre a teologia medieval. São Paulo, Companhia das Letras, 1998.

LedeSMA, Vilmar. Cleyde Yáconis: dama discreta. São Paulo, Imprensa Oficial, 2004, Coleção Aplauso.

Mello e SouzA, Gilda de. A idéia e o figurado. São Paulo, Duas Cidades, 2005.

MESQUITA, Alfredo. De como vim a conhecer Cacilda Becker e o que se seguiu. In: FERNANDES, Nanci e VARGAS, Maria Tereza. Uma atriz: Cacilda Becker. 2a . ed., São Paulo, Perspectiva, 1995.

MiCELI, Sérgio e MATTOS, Luis Fernando Franklin. (orgs.) Gilda, a paixão pela forma. Rio de Janeiro, Ouro Sobre Azul/Fapesp, 2007.

MignARD, Annie. Propos elementaires sur la prostitution. Les Temps Modernes, mars 1976. 
MIRA, Maria Celeste. O leitor e a banca de revistas. São Paulo, Olho d'Água/Fapesp, 2001.

MONTENEGRO, Fernanda. Viagem ao outro: sobre a arte do ator. Rio de Janeiro, Fundacen, 1998.

PISCITELLI, Adriana. Corporalidades em confronto: gênero e nacionalidade no marco da indústria transnacional do sexo. Revista Brasileira de Ciências Sociais, vol. 22, nº 64, 2007.

PONTES, Heloisa. Intérpretes da metrópole. História social e relações de gênero no teatro e no campo intelectual, 1940-1968. Tese de livredocência, Departamento de Antropologia da Unicamp, 2008.

PRADO, Luis André do. Cacilda Becker: fúria santa. São Paulo, Geração Editorial, 2002.

RATTO, Gianni. A mochila do mascate. São Paulo, Hucitec, 1996.

RAULINO, Berenice. Ruggero Jacobbi: presença italiana no teatro brasileiro. São Paulo, Perspectiva, 2002.

RodRIGUES, Nelson. Teatro completo de Nelson Rodrigues. $2^{\mathrm{a}}$ ed. Rio de Janeiro, Nova Fronteira, vol. 4, 2004. 2002. . A menina sem estrelas. São Paulo, Companhia das Letras,

SARLO, Beatriz. La pasión e y la excepción. Buenos Aires, Siglo XXI Editores Argentina, 2003. 